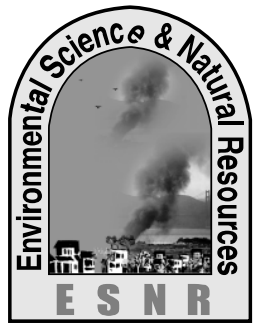

\title{
Fire Safety and Security System in High-rise Buildings in Tangail Pourashava
}

\author{
M. J. Uddin ${ }^{1 *}$, A. Adnan ${ }^{1}$, N. Sultana ${ }^{1}$, M. G. Muktadir ${ }^{1}$ and R. C. Ghosh ${ }^{2}$
}

${ }^{1}$ Department of Environmental Science and Resource Management Mawlana Bhashani Science and Technology University, Tangail,

${ }^{2}$ Department of Emergency Management, Faculty of Disaster Management, Patuakhali Science and Technology University, Patuakhali.

*Corresponding author: muhammadjasimuddin@yahoo.com

\begin{abstract}
Fire safety and security system in high-rise buildings has been a significant issue from the last century. However, there are numerous provisions for safety measures from such fires and the magnitude and nature of the problem of this hazard has been unknown. This study identifies the location of high-rise buildings in Tangail pourashava through an extensive survey and then identifies the unique fire safety problems of those buildings and their associated fire risk. As it turns out, most of those buildings are highly vulnerable to fire risk due to lack of major fire fighting equipments and defiance of related laws and regulations. The study then addresses the means to provide fire safety in those buildings from both design and codes perspectives. It elaborates on the need to provide both building and occupant based protection to achieve the best results. It concludes with an overview of the special problems associated with high-rise buildings combined with specific use and occupancy-related requirements, employee training and response.
\end{abstract}

Key words: Fire protection facilities, Fire equipments, High-rise building and Tangail pourashava

\section{Introduction}

According to the definition of the National Fire Protection Association (NFPA, 2012), high-rise buildings are defined as "buildings greater than 75 feet (approximately $23 \mathrm{~m}$ ) in height where the building height is measured from the lowest level of fire department vehicle access to the floor of the highest occupiable story" high-rise buildings can be categorized in different classes like office building, residential building, commercial building and health care facilities. Effectively employed evacuation strategies and other safety issues are associated with high-rise buildings (Ronchi and Nilsson, 2012; Hall, 2011). Providing the total safety in a high-rise building fire safety management is very important concept. It should be planned at the design stage using engineering approach. Specific fire safety plan should be conscripted with clear understanding on philosophy and assumptions of design for fire safety (Chow, 2001). Building fire risk study can be deliberated as the process of understanding and characterizing fire hazard, unwanted outcomes, and the likelihood of fire (Meacham, 2002). Lack of knowledge in terms of the behavioral features taking place during a high-rise building evacuation is still obvious (Kuligowski, 2011). Balancing the benefits of safety and costs of achieving the safety are necessary to make decisions about the applicable level of fire safety. Though it is more difficult to quantify the benefits, estimating the tolerable risk level in terms of costs and benefits, a number of studies have been made (Philips, 1994). In many countries, building codes are moving from prescriptive to performance based desires around the world (Hadjisophocleous and Bénichou, 2000). Author also revealed that, the negative aspects of the prescriptive codes is to advances made in fire science and engineering. A critical evaluation on the existing fire regulations for new high-rise buildings should be made before understanding whether the new regulations are appropriate (Hung and Chow, 2001).

From the inception of human civilization, the role of fire is very significant and still in the modern world its importance has not been reduced. As a source of energy, fire has various uses in our everyday living. Fire, if not manageable, can be disastrous for human settlements. Urban settlements of the world are more vulnerable to fire hazard due to the involvement of huge population in economic activities, industrial and other activities. Urban fire incidence is alarmingly increasing all over Bangladesh particularly in larger urban centers due to rapid unplanned urbanization and the absence of adequate safety measures in the city system (Islam and Adri, 2008). Tangail pourashava is roughly facing this hazard these days. The urban growth rate of Tangail district is increasing as it is close to the capital of Bangladesh, Dhaka. As the population size is getting larger day by day the number of high rise buildings is also increasing to cope with the added necessity of housing and accommodation. As the urbanization trend of the city has been developed more recently, there is still room for proper and effective city planning. Apart from that there has not been any fire event in any of the high-rise buildings so far. So, the developers and authorities still lack the urge for developing any proper considerations for the problems of fire events. Although, there are two fire service stations in the district, one in the Tangail pourashava and the other in Madhupur upazilla (BBS, 2011), an integrated framework for fighting fire hazard is still absent. According to Tangail fire service and civil defense station, 2016 all the fire incidents that has been happened so far is mostly in the market areas due to electrical problems and the consequences haven't been that much significant to raise any alarms in the local mass. According to our field survey there are 38 buildings in 18 wards of Tangail pourashava, which are 7 storied or above. It is not known what fire fighting arrangements are available in these buildings. Vulnerability appears to be high as these buildings are being used by a large number of people at a time. Though there hasn't been any fire incident reported in any of the buildings in our study area but some recent fire events in the capital raised some serious concern among the community and the authorities of Tangail pourashava of a significant fire threat as Tangail lies right next to the capital. 
A notable example of such incidence is the devastating fire occurrence at the Bangladesh Steel and Engineering Corporation (BSEC) Bhaban at Karwan Bazar in the Capital on 26 February, 2007. Despite having access to fire fighting equipment's on almost all the floors no one could use them due to lack of related knowledge and training. Twenty-five fire fighting units worked frantically for more than six hours to bring the fire under control. Three persons were killed and more than 100 were injured in this incidence (The Daily Star. October 31, 2014). Nine people died in a fire at a fivestoried building in Aga Sadek Road on 4 April, 2007 (Ahmed, 2008). It was a mixed occupancy building having shoe factory on ground floor and the residential units at the upper floors. On 13 March, 2009 a devastating fire engulfed the top floors of a 20 story office cum shopping center known as Bashundhara City Complex at Panthapath (Bdnews24.com. 13 March 2009) killing seven and injuring 50 people (Hossain, 2009). Although the Fire Service has to issue a clearance certificate to every high-rise building prior to occupation of the building, but there is hardly any evidence that it has issued such certificate on the basis of inspection after the completion of the structure. Any building above four stories must have provision for inhouse protection from fire, such as fire extinguisher, fire drills among its occupants and additional stair case for fire exits. But these facilities are almost absent in all high-rise buildings of the Tangail pourashava. The number of fire incidents in Bangladesh was 17504 in 2012, 17912 in 2013, 17830 in 2014, 17488 in 2015 and 16858 in 2016 (BFSCD, 2017). According to Tangail Fire Service and Civil Defense Station, 2016 in Tangail district there were 114 and 102 fire hazards in 2015 and 2016 respectively. Modern concept of 'fire safety' involves integrated measures on prevention, detection and protection at planning stage to execute effectively for saving the life and property from fire. There is almost nothing on preventive measures against fire in our legislation (Mahmud, 2009) which was a concluding remark about fire preventive legislation of our country. In technologically advanced countries, fire safety regulations have undergone many changes over the past decade. The revised fire precautions legislations include fire safety measures in the workplace to ensure worker's safety from risks at all times. On the whole awareness of the people, legislation of the government, equipment's of the fire fighters and planning of the planners shall have to reach in such a level from where protection and prevention would be possible from any fire incidences in high-rise buildings of Tangail pourashava.

\section{Objectives of the study}

The goal of the study is to generate knowledge and ideas about the possible fire hazards risk and recommend preventive measures to fight this phenomenon, particularly in Tangail pourashava. The present study is looking at the following specific objectives in order to achieve the broader goals mentioned above. The specific objectives of the study are-

- To know the distribution of high-rise buildings in Tangail pourashava.

- To study the existing fire protection facilities in the high-rise buildings of Tangail pourashava.

\section{Materials and Methods}

The study area is a city of Tangail district in the central region of Bangladesh. It lays $98 \mathrm{~km}$ north-west of Dhaka, the capital (Map1). It is one of the important cities of central Bangladesh and main urban area of Tangail district. The city is on the bank of Louhajang river. Tangail municipality was established in 1887 and it got shape as a separate district on 1st December, 1969. Tangail sadar thana was formed in 1962 and it was turned into an upazila in 1984. The total area of Tangail city is $35.22 \mathrm{~km}^{2}$. The city consists of 18 wards and 64 mahallas until 2016. It has a total population of 167412 (BBS, 2011). For the study both primary and secondary data were taken. The study method also includes a series of related activities. The first step of the study was to identify the high-rise buildings in Tangail pourashava. The identification of high-rise buildings were made in order to find out the number of high-rise buildings ( 7 and above) in each ward. Recent satellite images and existing studies had also been used for the study. Then, a questionnaire survey was carried out in 34 out of 38 high-rise buildings located in Tangail pourashava focusing on the existing fire fighting systems available in those buildings. Respondents of the questionnaire survey were owner, manager, caretaker and user of the buildings. Secondary sources of data had been collected from available documents (published and unpublished) sources (e.g. newspapers, published journal, books and data, etc.) togather information on fire incident and fire fighting systems in high-rise buildings. The data from the questionnaire survey had been processed and analyzed by using SPSS 11.1 software and MS Excel program. After data entry had been completed, simple one way tables and graphs had been prepared for the analysis to make the report understandable. The maps had been prepared by using Arc GIS 10.3 software. The study was conducted during October and November, 2016. 


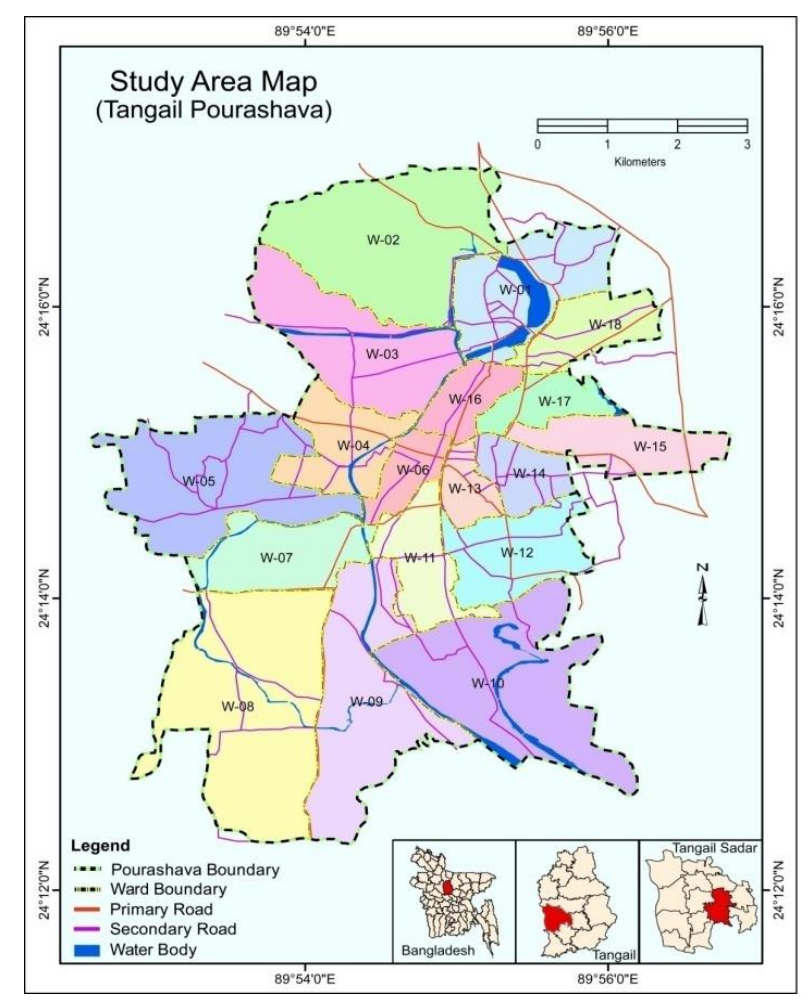

Map 1. Study area.

\section{Results and Discussion}

\section{Distribution of high-rise buildings}

In our study, we found 38 high-rise buildings within the Tangail pourashava. Map 2 shows their spatial

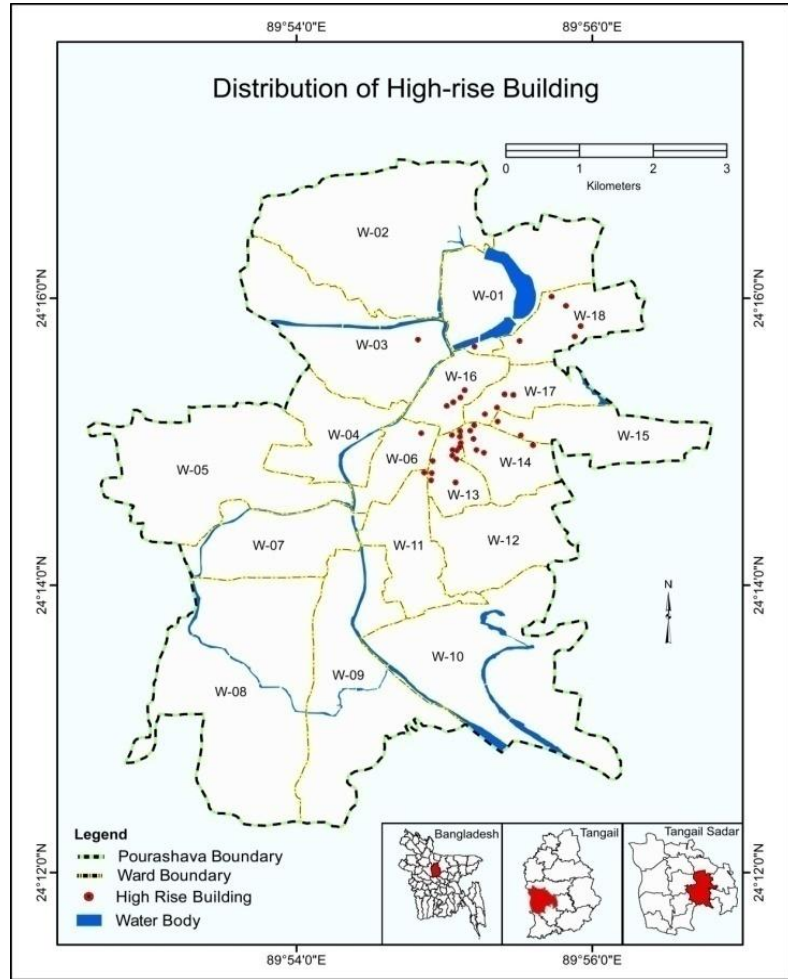

Map 2. Distribution of high-rise building in Tangail pourashava

distribution in Tangail pourashava. It is prevalent that the concentration of high-rise building is high along the main streets of the pourashava.

Table 1. Distribution of high-rise building in Tangail pourashava by wards, 2016

\begin{tabular}{|c|c|c|c|}
\hline $\begin{array}{l}\text { Ward } \\
\text { No. }\end{array}$ & Region & $\begin{array}{l}\text { Number of total } \\
\text { buildings }\end{array}$ & $\begin{array}{c}\text { Percentage } \\
(\%)\end{array}$ \\
\hline 1 & Akur Takur Para-North, Dewla, District hq & 1 & 2.63 \\
\hline 2 & Enayetpur & & \\
\hline 3 & West Akur Takur Para, North Kagmara, South Kagmara & 1 & 2.63 \\
\hline 4 & Bepari Para, Fakir Para, Bera Doma, Dighulia, Char Dighulia & - & - \\
\hline 5 & Kalipur, Lakshimpur, Sarutia, Shakrail & - & - \\
\hline 6 & College Para, Paradise Para, Par Dighulia-Part & 1 & 2.63 \\
\hline 7 & $\begin{array}{l}\text { Baluk Kandi, Bagbari, Patuli Bhabani Bagbari, Uttar Santosh-part, } \\
\text { Santosh Palpara }\end{array}$ & - & - \\
\hline 8 & Aloa Bhabani Pahim, Aloa Pahim, Dakshin Santosh-part & - & - \\
\hline 9 & $\begin{array}{l}\text { Aloa Baratia, Aloa Paikasta, Aloa Tarini, Baluk Kandi-Part, Char } \\
\text { Patuli, Purba Aloa, Aloa Bhabani }\end{array}$ & - & - \\
\hline 10 & Bajitpur, Berai, Basrakandi, Kazipur, Patal & - & - \\
\hline 11 & Berabuchna, Kachua Para, Kanda Para & 1 & 2.63 \\
\hline 12 & Adi Tangail, Bepari Para, Bil Para & & \\
\hline 13 & $\begin{array}{l}\text { Tangail Mahalla, Chayanir Bazar, Pachanir Bazar, Thana Para, Uttar } \\
\text { Thana Para }\end{array}$ & 13 & 34.21 \\
\hline 14 & $\begin{array}{l}\text { Purba Adalat Para, Adalat Para, Biswas Betka-part S.W corn, Shaha } \\
\text { Para }\end{array}$ & 6 & 15.78 \\
\hline 15 & Ashekpur, Biswas Betka-Part & 2 & 5.26 \\
\hline 16 & Akur Takur Para-part, Par Dighulia-Part & 4 & 10.52 \\
\hline 17 & $\begin{array}{l}\text { Kumudini College Para, Munshi Para, Registry Para, Biswas Betka- } \\
\text { west }\end{array}$ & 4 & 10.52 \\
\hline 18 & Kodalia, Sabalia & 5 & 13.15 \\
\hline \multicolumn{2}{|r|}{ Total } & 38 & 100 \\
\hline
\end{tabular}


Tangail pourashava consists of 18 administrative zones described as ward. The study shows that the distribution of high-rise building within Tangail pouroshava is not uniform in all wards. Ward 13 covering the Chayanir Bazar, Pachanir Bazar, Thana Para, Uttar Thana Para areas includes 16 high-rise building $(42.10 \%)$, whereas the wards 01, 03, 06 and 11 covering mostly District Gate, Akurtakur Para, College Para and Kachua Para areas respectively, contains only one such building each accounting for $10.52 \%$ collectively (Table 1 ). The second highest concentration was found in the ward no. 14 covering mostly Adalat Para and Biswas Betka areas accounting for 6 such buildings. It is prominent that High-rise building are located mainly in the ward no. $13,14,16$ and 17 which is the central business district area of Tangail pouroshava.

\section{Existing fire fighting facilities}

Fire fighting, by its nature is a difficult task. It can be even more strenuous when there is lack of fire fighting facilities and it is likely to increase fire hazards as well as risk to fire fighters. Fire fighting facilities such as fire control panels, electric sub-Station, generator (any), standby generator (for fire), control panel, lighting conductor, exhaust fan, any kind of fire equipments, fire extinguisher, sand tub, smoke detector, heat detector, radiation detector, fire alarm, intercom, emergency stair, emergency exit indicator, hose fittings, electric pump, diesel pump, jocky pump, fire lift, fire fighters, fire trained persons, emergency helicopter landing or lifting, basement water storing Capacity $\geq$ 50000 liter, source of water, fire fighters lifts, ventilation systems etc. are basic facilities needed to assist fire fighters and to aid occupants to evacuate the premises. The lack of any single part will be significantly detrimental to Fire Rescue Servic operations. This study attempts to find out the existing status of fire fighting facilities of HRBs in Tangail Pourashava

Due to the universal availability of water, it is considered to be the main fire extinguishing agent in Bangladesh while dealing with fires. The study shows (Table 2) that about all of the sample building's main source of water supply is water supply line provided by Tangail pourashava (Map 3) along with 28 buildings $(82.35 \%)$ own tubewell. The rest 6 buildings don't have any tubewell. Table 3 reveals that 31 buildings $(91.18 \%)$ have only one underground reserve tank and the remaining 3 buildings $(8.82 \%)$ don't have any.
Table 2. Source of water in high-rise building in Tangail pourashava

\begin{tabular}{|lll|}
\hline Water Sources & Building no & $\begin{array}{l}\text { Percentage } \\
(\mathbf{\%})\end{array}$ \\
$\begin{array}{l}\text { Pourashava supply } \\
\text { line and tubewell }\end{array}$ & 28 & 82.35 \\
$\begin{array}{l}\text { Only pourashava } \\
\text { supply line }\end{array}$ & 6 & 17.64 \\
Total & $\mathbf{3 4}$ & $\mathbf{1 0 0}$ \\
\hline
\end{tabular}

Source: Field survey. November, 2016

Table 3. Location of water reservoir in high-rise building

\begin{tabular}{|lll|}
\hline Location & Building no & Percentage (\%) \\
$\begin{array}{l}\text { Ground floor } \\
\text { and roof top }\end{array}$ & 31 & 91.18 \\
Rooftop only & 3 & 8.82 \\
Total & $\mathbf{3 4}$ & $\mathbf{1 0 0}$ \\
\hline
\end{tabular}

Source: Field survey. November, 2016

Table 4. Reservoir capacity at ground floor in High-rise building

\begin{tabular}{|lll|}
\hline Capacity (liter) & Building no & Percentage (\%) \\
$0-10000$ & 13 & 41.93 \\
$10000-20000$ & 7 & 22.58 \\
$20000-30000$ & 4 & 12.90 \\
$30000-40000$ & 1 & 3.22 \\
$40000-50000$ & 1 & 3.22 \\
$50000-60000$ & 3 & 9.67 \\
$60000+$ & 2 & 5.9 \\
Total & $\mathbf{3 4}$ & $\mathbf{1 0 0}$ \\
\hline
\end{tabular}

Source: Field survey. November, 2016

Table 5. Reservoir capacity at rooftop tank in highrise building

\begin{tabular}{|lll|}
\hline Capacity (liter) & Building no & Percentage (\%) \\
$0-10000$ & 22 & 64.7 \\
$10000-20000$ & 3 & 8.82 \\
$20000-30000$ & 4 & 11.76 \\
$30000-40000$ & 2 & 5.9 \\
$40000-50000$ & 3 & 8.82 \\
Total & $\mathbf{3 4}$ & $\mathbf{1 0 0}$ \\
\hline
\end{tabular}

Source: Field survey. November, 2016 


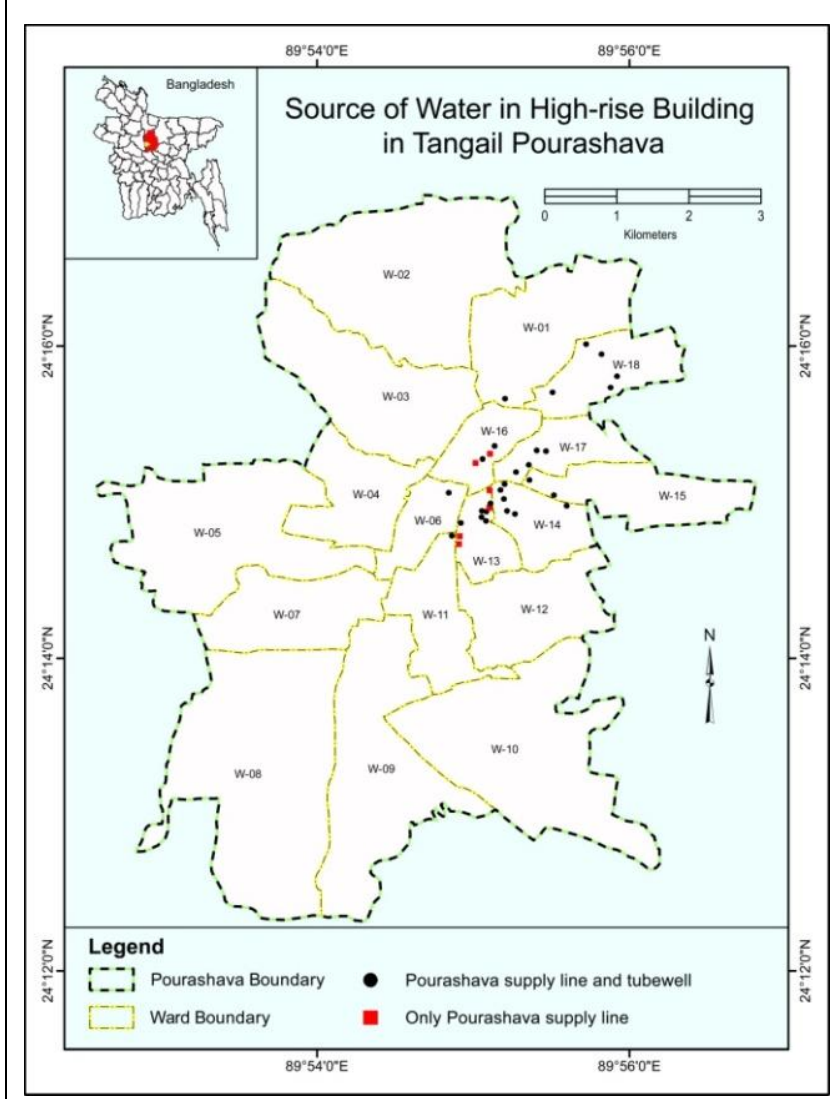

Map 3. Source of water in high-rise building in Tangail Pourashava

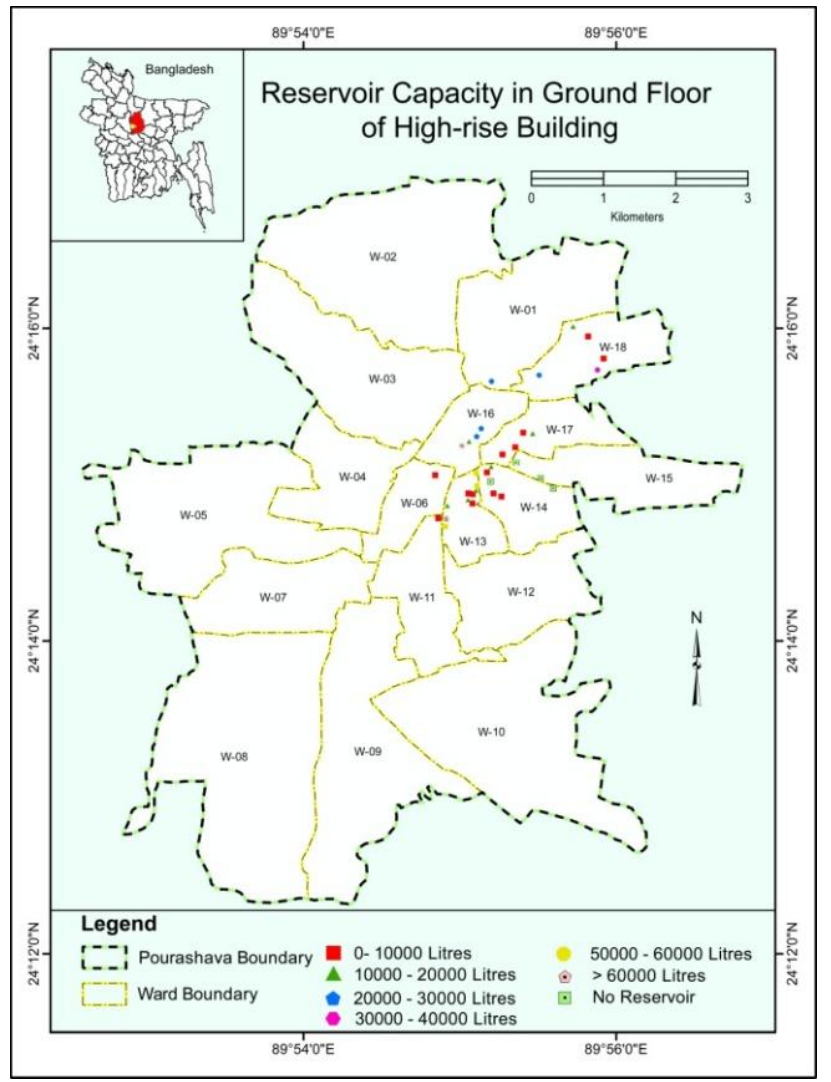

Map 5. Reservoir capacity in ground floor of high-rise Building in Tangail pourashava.

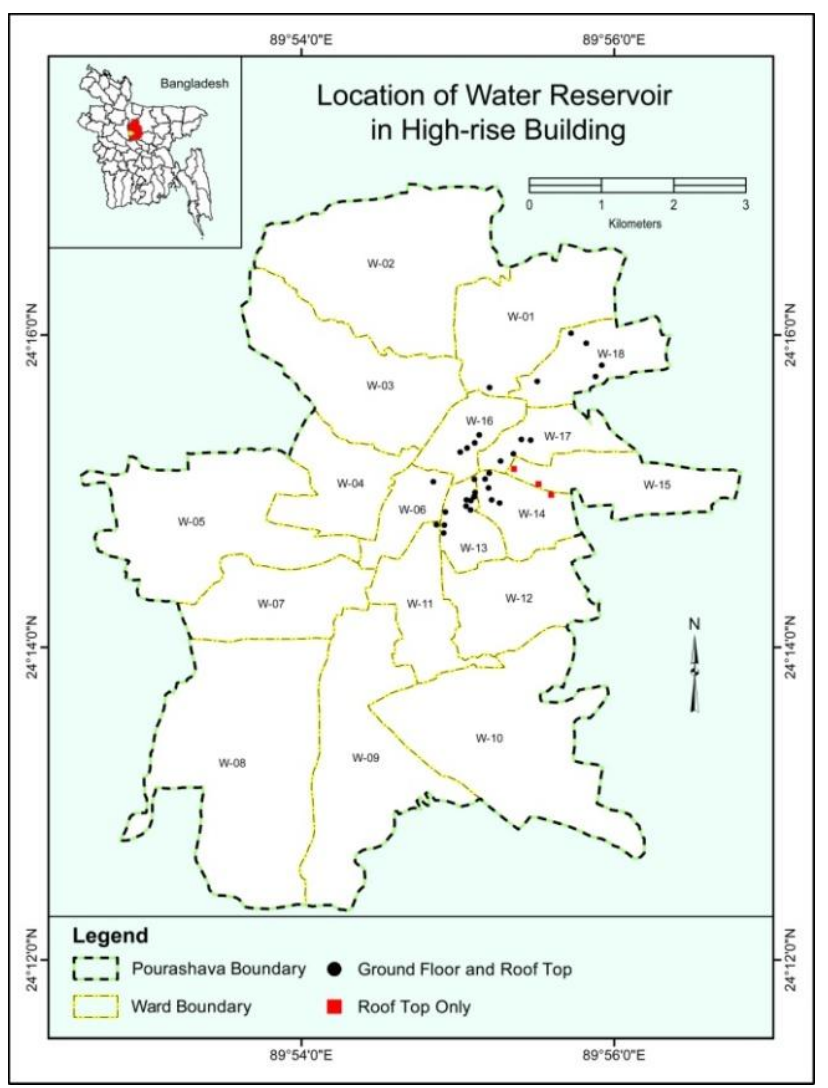

Map 4. Location of water Reservoir in high-rise building in Tangail pourashava.

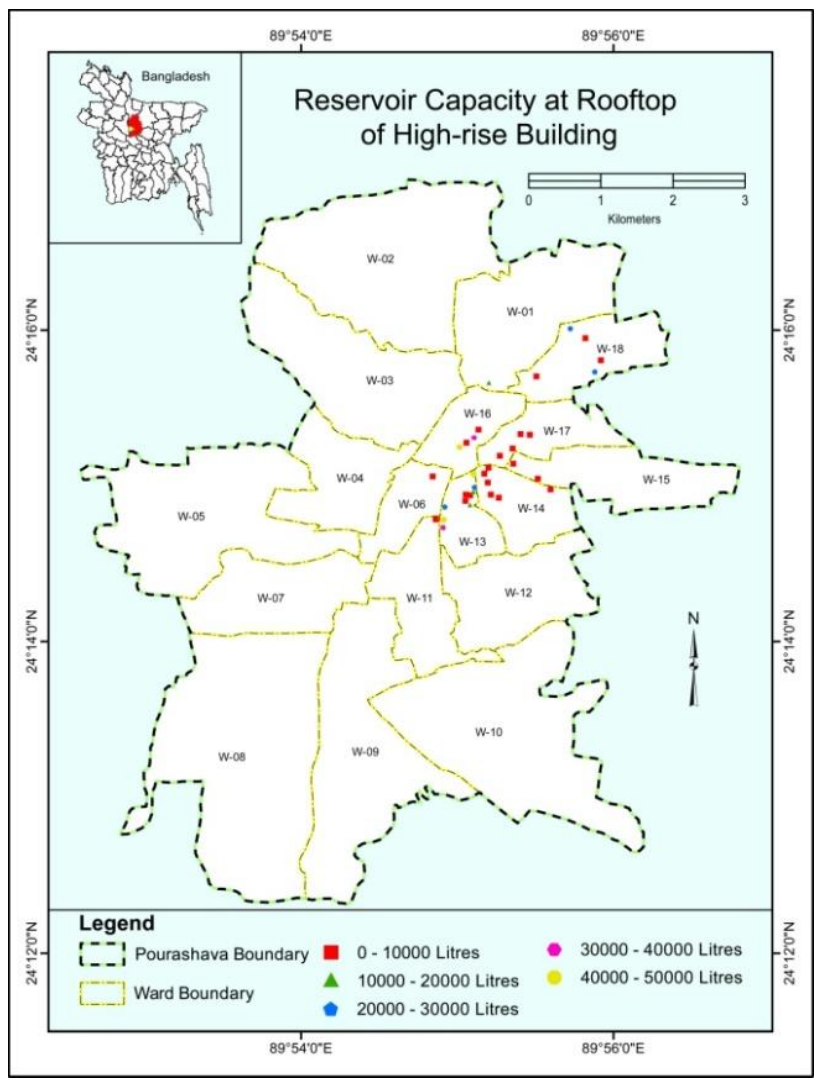

Map 6. Reservoir capacity at rooftop of high-rise Building in Tangail pourashava. 
As stated by the Bangladesh National Building Code, 1993 every high-rise building must have basement water reservoir and its capacity must be more than 2 , 00,000 liters and half of the reserve water should be stored for the fire safety use. Sadly, none of the buildings fulfilled the requirement and only 2 buildings $(5.9 \%)$ found to have up to $60,000^{+}$liters capacity (i.e. half of the required capacity, Table 4). These findings, therefore, clearly indicates that neither of the buildings didn't follow the BNBC rules and thus in time of any fire hazard in high-rise building there will be a serious water shortage for fire fighting. According to Bangladesh National Building Code (BNBC) every building must have one roof tank and its capacity must be minimum 80,000 liters. In our study, all the buildings have roof tank reservoir (Table 3 ), but no building fulfilled the capacity requirement. Majority of the buildings ( $41.93 \%$ ) have the capacity up to 10,000 liters and only 3 buildings $(8.82 \%)$ were found to have the capacity between 40000 and 50000 liters (Table 5).
Like all the urbanized cities, Tangail pourashava is also experiencing a vertical expansion due to high density of population and acute shortage of built up areas (flood free areas) in and around the city. Thus, high-rise buildings are growing with the development of the city. But it has been found that the buildings were built without proper planning, proper management and fire fighting system. The recent study observed that out of the 34 surveyed buildings, 27 buildings $(79.41 \%)$ have one kind of fire fighting tool i.e. all of them have fire extinguisher (27 buildings). 10 buildings (29.41\%) were found to have hose pipe and water supply arrangement in each floor. Only one building has smoke detector and one has an emergency stair. 26 buildings $(76.47 \%)$ have generator and 6 buildings $(17.64 \%)$ have electric substation facilities. Apart from those no other fire fighting equipments were found. It appears from the study that, most of the buildings have a common traditional fire extinguisher $(79.41 \%)$ as fire fighting facilities (Table 6)

Table 6. Available fire fighting equipments/facilities of high-rise building within Tangail pourashava

\begin{tabular}{|c|c|c|}
\hline Type of Facilities/Equipments & $\begin{array}{l}\text { Number of Buildings } \\
\qquad(\mathrm{N}=34)\end{array}$ & $\begin{array}{c}\text { Percentage of Total Surveyed } \\
\text { Buildings }\end{array}$ \\
\hline Electric Sub Station & 6 & 17.64 \\
\hline Electric Sub Stations Followed Specific rules & - & - \\
\hline Generator (any) & 26 & 76.47 \\
\hline Standby Generator (for fire) & - & - \\
\hline Control Panel & - & - \\
\hline Lighting Conductor & - & - \\
\hline Exhaust Fan & 6 & 17.64 \\
\hline Any kind of Fire equipments & 27 & 79.41 \\
\hline Fire Extinguisher & 27 & 79.41 \\
\hline Sand Tub & - & - \\
\hline Smoke Detector & 1 & 2.94 \\
\hline Heat Detector & - & - \\
\hline Radiation Detector & - & - \\
\hline Fire Alarm & - & - \\
\hline Intercom & 5 & 14.7 \\
\hline Emergency Stair & 1 & 2.94 \\
\hline Emergency Exit Indicator & - & - \\
\hline Hose Fittings & 10 & 29.41 \\
\hline Electric Pump & 34 & 100 \\
\hline Diesel Pump & - & - \\
\hline Jocky Pump & - & - \\
\hline Fire Lift & - & - \\
\hline Fire Fighters & - & - \\
\hline Fire Trained Persons & - & - \\
\hline Emergency Helicopter Landing or Lifting & - & - \\
\hline Basement Water Storing Capacity $\geq 50000$ liter & 5 & 14.7 \\
\hline
\end{tabular}

Source: Field survey. November, 2016. (- absent)

Telephone system is very necessary equipment or system for the fire safety and security in every high-rise building in a city. The study shows only 5 buildings have such facility, which helps emergency communication. No buildings were found to have fire alarm, heat detector, radiation detector, fire lift or control panels. Though 2 of the buildings were found to have smoke detector and emergency escape, which is negligible. These modern technologies are very essential, especially for Tangail pourashava where most 
of the high-rise buildings are multi functional. Emergency lights help occupants to safely escape the building in the event of a power failure. According to the present study, only 6 buildings were found to have exhaust fan in their basement and neither of the buildings have any helipad for emergency service.

In a high-rise building occupants suffer mainly because of difficulty in gaining access to outside due to the usual large number of building population in the event of a fire hazard. Major fires in high-rise buildings often result in injuries, fatalities and millions of dollars in property losses. Regarding possible obstacles for evacuation during fire, a significant case could be insufficient stairs in high-rise buildings that accounted for roughly $56 \%$ of the surveyed buildings.
It can be even more fatal due to complete absence of emergency stairs in all of the buildings except one. The same goes for the fire lifts that none of the respondents had any idea about. Almost $70 \%$ of the surveyed buildings have a narrow front side road. While undertaking a rescue operation, fire fighters must consider the precautions necessary to control the fire and assure the safety of themselves as well. Proper ventilation simplifies and expedites rescue by removing smoke and gases that endanger trapped or unconscious occupants. The study shows that rescue operation could be hampered due to lack of appropriate and adequate rescue tools for our fire fighters. Lack of fire fighters, narrow road, glass and gill cover, insufficient water, lack of water supply arrangement, lack of rescue tools, lack of open space, lack of fire lift, lack of emergency stairs, narrow stairs, insufficient stairs (Fig.1).

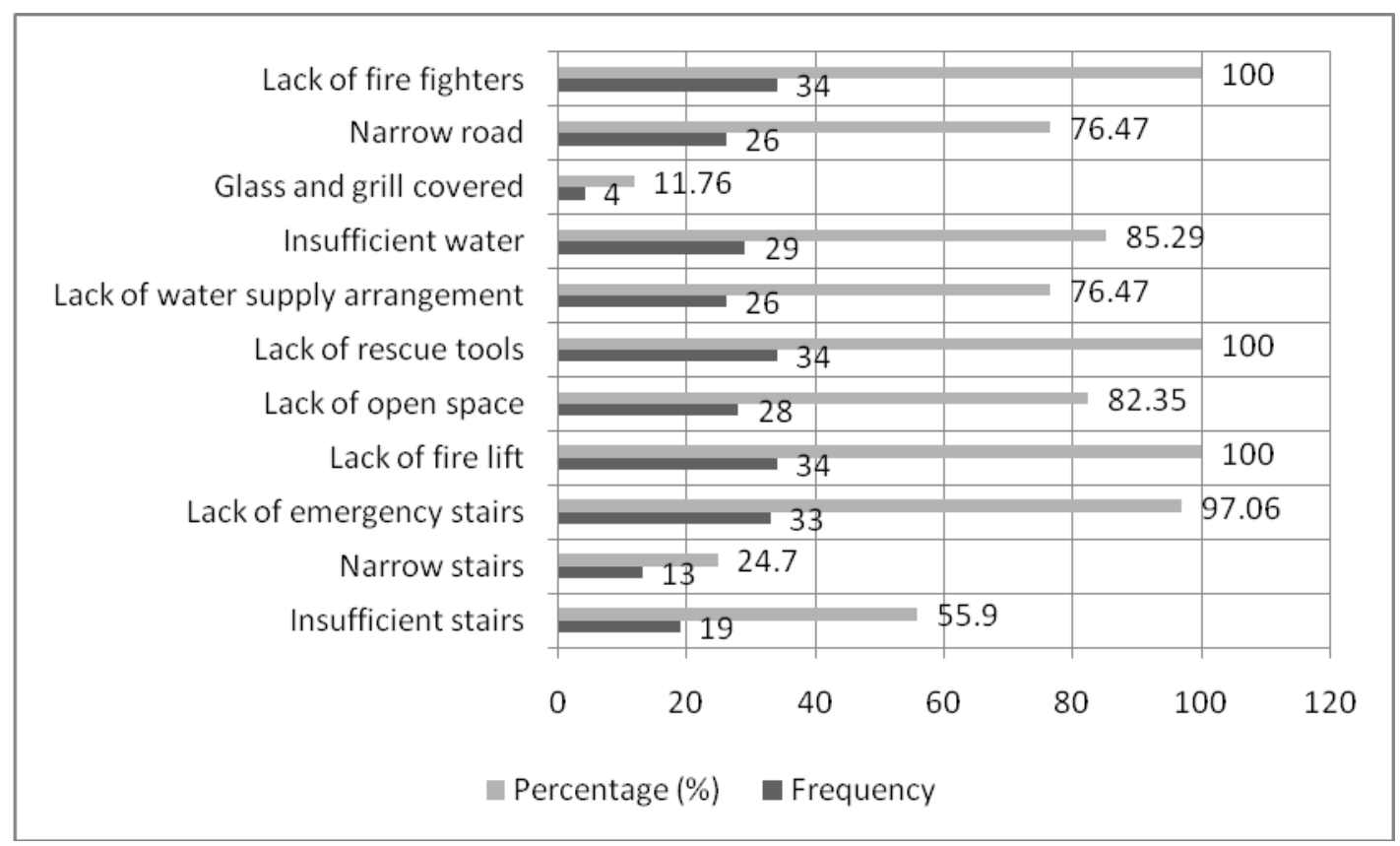

Fig. 1. Predicted obstacles of evacuation, rescue operation, fire control and property protection in case of any fire hazard in high-rise building.

\section{Conclusion}

In the recent years, fire incidences were frequently recorded in several high-rise buildings in Bangladesh. It is alarming if such incidents keep taking place in highrise buildings. Because, casualties of life are more in high-rise buildings as people cannot easily come out of the buildings. Secondly, it is difficult to fight fire in high-rise buildings. And thirdly, losses are perhaps more if fire takes place in high-rise buildings as there is nothing left. Theoretically, fire should not take place in high-rise buildings if these are built maintaining BNBC and BCR rules properly. However, despite such theoretical notion, it takes place as an accident. When such accidents occur frequently, it needs proper investigation to find out the reason behind it. Based on our study following recommendations were made.

- Design and construction guidelines of BNBC (Bangladesh national building code) and BCR (Building construction rules), should be strictly followed.
- All the existing high-rise buildings should be checked by appropriate authorities and all the owners should be brought under BNBC.

- Development of more fire brigade station and decentralization of their stations.

- Every high-rise building should have minimum 2 staircases and sprinkler system should be made mandatory for basement parking and other risk areas where large quantities of combustible materials are stored.

- The road which abuts a high rise building to be constructed should be more than 30 feet width.

- $\quad$ First aid fire fighting appliances should be provided and installed.

- Lifts should not be used as means of evacuation and collapsible gates should not be provided for the lift.

- Landing doors of lifts should open to ventilated lobby and "Fireman switch" should be provided for each lift. 
- Conserve open space, water bodies, playground, park etc. within the city to facilitate fire fighting. These facilities can be used for other purpose also.

\section{References}

Ahmed, S. 2008. Fire at Aga Sadek Road, The Daily Star. August 10, 2008. http://www.thedailystar.net/news-detail-49676

Bangladesh bureau of statistics (BBS). 2011. Statistical yearbooks Bangladesh 2013. Statistics and information division, Ministry of planning.

Bangladesh Fire Service and Civil Defence (BFSCD). 2017.http://www.fireservice.gov.bd/site/page/18e0 8e09-ad74-4aa6-9494-84d1fdc18ad3/Fire-Incident

Bdnews24.com. 13 March 2009. Bashundhara City turns towering inferno, http://bdnews24.com/bangladesh/2009/03/13/bash undhara-city-turns-towering-inferno.

Chow, W. K. 2001. Review on Fire Safety Management and Application to Hong Kong. International Journal on Engineering Performance-Based Fire Codes, 3(1): 52-58.

Hadjisophocleous, G. V. and Bénichou, N. 2000. Development of Performance-Based Codes, Performance Criteria and Fire Safety Engineering Methods. International Journal on Engineering Performance-Based Fire Codes, 2(4):127-142.

Hall, J. R. 2011. High-Rise building fires. National Fire Protection Association. Fire Analysis and Research Division.

Hossain, F. 2009. Fire at Bangladesh's Largest Mall Kills 7, abc news. 13 March, 2009. https://web.archive.org/web/20090327153647/http ://abcnews.go.com/International/wireStory?id=707 4414
Hung, W. Y. and Chow, W. K. 2001. Review on Fire Regulations for New High-Rise Commercial Buildings in Hong Kong and a Brief Comparison with Those in Overseas. International Journal on Engineering Performance-Based Fire Codes, 3(1): 25-51.

Islam, M.; Monowarul and Adri, N. 2008. Fire Hazard Management of Dhaka City: Addressing Issues Relating to Institutional Capacity and Public Perception, Jahangirnagar Planning Review, 6: 57-67, Jahangirnagar University, ISSN 1728-4198

Kuligowski, E. D. 2011. Terror defeated: Occupant sensemaking, decision-making and protective action in the 2001 World Trade Center Disaster. Dissertation, University of Colorado, US.

Mahmud, Lt. Cdr. (Retd) A. H. M, 2009. Fire safety in workplace : Bangladesh perspectives, The Daily Star, $11 \quad$ July, 2009. http://www.thedailystar.net/news-detail-96324

Meacham, B. J. 2002. "Building fire risk analysis", SFPE Handbook of Fire Protection Engineering, National Fire Protection Association, Quincy, MA, pp. 5-153.

NFPA. 2012. NFPA. 101 Life Safety Code. National Fire Protection Association, Quincy (USA)

Philips, W. G. B.1994. "Simulation models for fire risk assessment", Fire Safety Journal, 23(2): 159-169.

Ronchi, E. and Nilsson, D. 2012. Fire Evacuation in High-rise Buildings: a Review on Human Behaviour and Modelling Research. Lund University. Department of Fire Safety Engineering and Systems Safety.

The Daily Star. October 31, 2014. Fire at BSEC building doused, http://www.thedailystar.net/fireat-bsec-building-doused-48275. 